\title{
Market Research and Development under the Network Environment
}

\author{
Tingting FU \\ Jinan Vocational College \\ Jinan,Shandong 250000 China
}

\begin{abstract}
With the development of computer and network communication technology, the Internet also increasingly be used in various fields of society widely, especially the business of marketing activities. The Internet age is not only to bring huge business opportunities, but also give new challenges to traditional marketing activities .It greatly impacts the theory and practice of the past marketing. The concepts and methods of traditional marketing are no longer adapted to the new environment and changes in the world today. This requires enterprises have to make the appropriate change and innovation to adapt to the times of the marketing requirements in the mode of marketing activities, ideas, strategies and means. In this paper, the development and changes in the market environment caused by the current network technology are analyzed and researched. It will explore how to adapt to the current network environment and establish marketing strategies.
\end{abstract}

\section{Keywords- Internet age; marketing; strategy}

\section{INTRODUCTION}

The emergence and development of the Internet has broken the restrictions of time and space on marketing. Enterprises can build long-term and reliable relationships of supply and demand with consumers through internet. Thereby it enhances the degree of association of enterprise products and customer needs. This not only provides better quality products and personalized service to meet the needs of customers but also greatly reduces the operating costs. Thus they will achieve a win-win result. At present, the marketing network environment has the following aspects of characterized.

\section{A. Marketing across time and space, media shows the full range}

Marketing under the network environment revolutionize the traditional marketing methods. It has broken the limitations of time and place of traditional marketing and other aspects greatly reducing operating costs. In addition, the customer can perform two-way communication with the enterprise through the network at any time and any place. They can request and response with business issues directly. No matter how much the strength and size of the enterprise, the strength and size of the product are, the international marketing can be carried in network platform out on an equal footing which greatly increases the degree of international marketing.

In addition, known as the fourth media, the Internet also has a strong transmissible. Enterprise can not only extend the brand image and all-round, three-dimensional ground advertising companies and products through the network, but also can greatly improve the acceptance of information recipient.

\section{B. Consumer satisfaction for the purpose, marketing steering to personalized}

Marketing under the network environment can be an interactive two-way exchange of information. Marketing can be bottom-up approach. Consumers can share the company's marketing information to form an equal relationship which greatly improves the position of consumers in the marketing process. Thus it effectively strengthens customer loyalty.

Marketing under the network environment effectively reduce the cost of communication and information processing costs of marketing activities for traditional mass marketing based on supermarkets and television advertising and large-scale production by using network technology and database technology. In addition, companies can collect worldwide customer's individual needs in network and then clear target market and customers. It allows enterprises design certain products on the basis of large-scale production but also meeting with the specific needs of individual customers.

\section{Communication}

In the network environment, consumers can participate in the process of marketing activities actively. Consumers can have a two-way communication and exchange directly with the companies on the product design, production, pricing and service and other issues through the network. In this way, companies can not only provide product information to customers through a network, but also can make timely and truthful information to get their feedback. It can provide a scientific and effective evidence for enterprise to timely adjustment of marketing strategy. So that the internal organizational structure has been continuously optimized and improved.

\section{THE DEVELOPMENT OF NETWORK TECHNOLOGY CHALLENGE THE MARKETING}

As network technology is rapidly developing, especially the personal computer and the Internet, an interconnected, global digital business era is coming. Development of network technology brings people more convenient and efficient means for communication and access to information. The network has become the biggest consumer market in new markets providing great business opportunities for every enterprise. But it challenges traditional marketing.

A. The development of network technology leads to the transformation of marketing model

The development of Internet marketing makes computerized possible. And marketing of computerized causes marketing model changed dramatically. This shift in marketing model provides a favorable means for small 
businesses to enable them to outwit those mighty big businesses in the past.

Under the computerized marketing model, by means of Internet, companies can lower the cost to complete the following tasks: establishing new sales channels connected to the personal computers of users; reach new potential customers; offering new channels for deeper advertising; transforming a large number of variable information into applicable information to meet the needs of; to collect large amounts of consumer information, so that the consumeroriented marketing campaigns will be clearer, more targeted; establish a more effective channel to automatically solve the problems, answer consumers' questions; sensitively collect consumers' feedback and using feedback to improve products, services and sales.

\section{B. The development of network technology led to the marketing from mass marketing no difference shift to personalized marketing}

In the 1950s, large-scale marketing began to change the society by means of television advertising, shopping malls, supermarkets, large-scale production facilities, as well as the concept needed by high-volume consumer. Large companies have invested a lot of money in the large-scale consumer advertising. By contending market share, they earned, grow and make it difficult for new entrants to insert their fields. While the development of Internet, the whole world is into a computer network interwoven world. Network brings miniaturization, new age diverse and complex growing. Global market with a large number of consumers chooses replaced the limited domestic market consumer choice. Computerized productions make the products rich and varied selections which are better to meet the special requirements of specific customers. We are moving from mass production which based on small differences in the standard product to personalized, short cycle, information-rich and endless variations of production changes.

\section{The development of network technology has led to the marketing shift from large brand to brand diversification}

In the days of mass marketing, smaller companies cannot compete with big companies that invest heavily in advertising. Consumers generally accepted the mega brands of large companies. However, under the unprecedented development of network technology, very small companies can also have a special interest consumer groups. Other small brands make their prices very cheap because of the rapid development of modern technology. At the same time, the diverse of effective choice of today's consumers also provides an opportunity for small companies continue to erode the old market overlord territory. One of the advantages of the network is that some small quantities of products for a small group of special customers are growing rapidly in the global.
D. The development of network technology enables the traditional one-way exchange of information to replace the dissemination of information as possible

Marketing is a complex two-way learning process. Prior to the purchase behavior, consumers want to know the details of the products and services which interests to him and will raise some questions. Sellers want to find potential customers. Most of the traditional media provide one way exchange of information which does not work in this regard.

Internet provides one-to-one exchange of information with interactive features. Businesses and consumers can have a dialogue over the Internet. Understanding of consumer needs, companies can also encourage customers to participate in product decisions, allow customers to choose the color, style, packaging, transportation methods and place an order on their own. In the process of customization, sales of products are for meeting the special requirements of customers and allowing them to participate. The more they participate, the greater the opportunity is to sell the products.

\section{E. Online trading change the commodity trading, \\ commercial movement and the way they compete}

Online trading is built on the basis of mutual trust, mutual obligations. Due to the defect of the third party and without any third-party enforcer sanction violations and, therefore, the main credit online trading is a very important thing.

Under the conditions of the network technology, information flow has become the dominant factor of commercial movement in the process of commodity circulation and take the media and the leading role in business flow (the value of goods movement) and logistics (the value of goods movement). Under IT conditions, the price information of a commodity will become public information. Therefore, non-price competition online trading has become the basic way of business competition.

\section{IN NETWORK MARKETING}

In recent years, Internet applications in the commercial and marketing has rapid development. Network marketing can expand the horizons of companies, re-define the scope of the market, closer to consumers, and replace human communication and one way to media promotions, changes in market competition morphology, impact and influence of traditional enterprises. It mainly shows in the following aspects.

\section{A. Changes in Marketing Environment}

Internet marketing means that the market economic tends to be liberalization. The methods of market trend to be paperless. Trading is more emphasis on speed. Businesses and consumers establish direct communication of the interactive relationship. The distance between production and consumption significantly shortened. Brokers lose control of information and their roles have been weakened. The information is greatly increased. Market uncertainty is greatly reduced according to enhancing production decisions. Consumers will have more in-depth comprehensive 
understanding of products and have more selections .Their buying behavior will be more rational.

\section{B. Reforming the organization of enterprise}

Internet companies have been promoting the internal network to flourish. Internal and external company communication and management needs to rely on the network as the main channels and information sources. Its impact include: the reduction of business and direct sales personnel, reducing layers of management and organizational flattening, channel shortening, the rise in the external corporate virtual organization. These effects and changes will encourage enterprises to carry out reorganization.

\section{The shift patterns of competitive}

The free and open Internet era makes the market competitive and transparent. Enterprises can grasp the product information and marketing behaviors of competitors. So the key to victory lies in how timely acquisition, analysis, use of this information obtained from network to develop competitive strategies. Besides, how to use the network to form a strategic alliance and coalition formed by the scale of resources to create competitive advantage. This will also be an important way to the future business.

\section{Reengineering relationships with Customer}

Network marketing companies are in a customer-focused competition patterns. Thus analyzing customer needs, seeking to expand the customer base, closing the relationships with customers, retaining customers, and guiding customers to establish critical business and network marketing virtual sense of trust. The target market, the customer type, product type of the Internet age will be very different with the past. So across the gap of geographical, cultural, temporal to recycle customers' relations requires many innovative marketing behaviors.

\section{E. Inevitability of transnational business}

The functions of Internet across time and space and coherent global making costs far less than the cost of global marketing area of marketing.Corporates integrated marketing resources from anywhere in the world and quickly meet the demand. So companies have to implement global marketing. Enterprise in network era not only should be familiar with the characteristics of transnational market customers, win the trust and meet of their needs, but also to contact and arrange transnational production, transportation and service through the network.

\section{INTERNET MARKETING STRATEGIES}

What kind of strategies enterprises, as the main network marketing, have to promote online marketing. They should have a correct understanding of the opportunities and challenges generated by the enterprise network and establish a network marketing concept. Some think the network's impact on a par with the industrial revolution. It is proved that the Internet have a catalyst for global economic integration. Because using the Internet and the application of network marketing improve operations, develop new markets, enhance the competitiveness of enterprises. Large companies have been considered it to be the global minimum costing and the most efficient way. Network marketing is the electronic and network of traditional marketing activities and a complement and deepening to traditional marketing. Therefore ignoring the network marketing business is bound to fall behind in the current business activities. Leaving the existing network behind, marketing campaign cannot exist alone and develop.

Optimize the internal organization and management with the appropriate agency personnel to facilitate the extension of network marketing. To organize the person responsible for coordinating with various departments and internal links; selecting of a group of network marketing, planning consultants and technical personnel who are specifically improving the quality and level of service of network marketing for enterprises.

According to the new market environment and the actual situation of enterprises, they should adapt to network marketing to develop marketing strategies, take advantage of the implementation of the specific objectives of Internet marketing such as: corporate image, expand market space, user survey response, improve service, seeking partners and so on.

Planning rationally and building corporate website. Corporate website is the basis of network marketing in general which include business profiles, company news, products catalog, product search, product price, online ordering, sales network, service, contact information and other projects. Meanwhile corporate website should focus on personalized, organized network marketing activities by the necessary of marketing strategy.

\section{CONCLUSIONS}

With the advent of the Internet age, a huge change from traditional information distribution and acceptance appeared. It not only changed the way people work, study and living environment for the exchange, but also greatly changed the business ways, philosophy and organizations from the past. Enterprise can continue growing if they actively face the challenges brought to marketing network environment and develop appropriate measures and strategies.

\section{References}

[1] Li Zhongjun. study of retail banking network environment integrated marketing strategy. [D]Southwestern University of Finance and Economics, 2013.

[2] Huang Yan The marketing revolution of network environment [D]. Huaqiao University, 2001.

[3] Chen jie the marketing sales under the network environment [J] business culture (Academic Edition), 2010,11: 194-195.

[4] Yang Xi Qian.The study in Marketing Strategy of securities brokerage business under network environment [D]. Xi'an University of Technology, 2006.

[5] Liu wei The marketing models On the social network environment [J] Modern Marketing (HEAD), 2014,08: 48.

[6] Liu Li The study of Marketing Strategy under the Network Environment [J] Industrial Technology \& Economy, 2005,05: 127-128. 